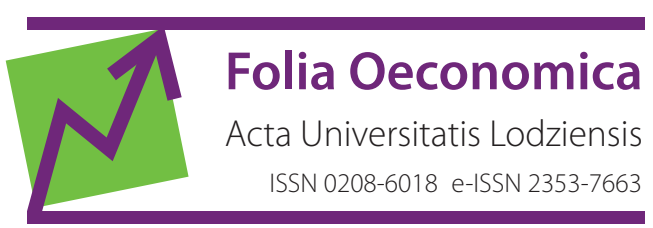

www.czasopisma.uni.lodz.pl/foe/

2(347) 2020

DOI: http://dx.doi.org/10.18778/0208-6018.347.02

\title{
Beata Bal-Domańska
}

Wrocław University of Economics, Faculty of Economics, Management and Tourism in Jelenia Góra

Department of Regional Development, beata.bal-domanska@ue.wroc.pl

\section{The Situation of Youth on the European Labour Markets - Econometric Analyses}

\begin{abstract}
The phenomenon of low professional activity of young people, especially those not in employment, education or training represents an important element of socio-economic policy considered on the global forum. The Reports covering the problem of youth on labour markets are highlighting the difficult situation in this respect in many countries worldwide. The situation of youth on the markets in individual EU countries is strongly diversified, e.g. in terms of time of starting professional activity. The purpose of the paper is the classification of European labour markets according to the characteristics of the situation of young people. The cluster methods for analysis of youth labour markets diversification have been conducted, and econometric models have been used to assess the relations between the employment rate among youth and the part-time agreements popularity.
\end{abstract}

Keywords: cluster analyses, econometric models, youth, labour market, European Union member states

JEL: C38, J21 


\section{Introduction}

Labour market is one of the production factors operating in market economy (Cazes, Verick, 2013; Dylkiewicz, 2013). Its function is to allocate and re-allocate human resources. The generational replacement of workers, resulting from the commencement and termination of the occupational mobility period by the subsequent generations is an important problem of the labour market. Creating jobs for people starting their professional career is associated with numerous challenges related to the transition process from the educational system to the real world of work, such as using the new potential, skills and perspectives, as well as the transfer of knowledge and experience. The entry of young people into the labour market is determined by many factors, among which the following can be listed: the availability of jobs, the level of education, adaptation skills to the actual needs of the labour market, labour market and employment flexibility, the method of rewarding people who gain experience. The phenomenon of low employment activity among young people, primarily the ones who neither work nor continue education, remains an important component of the socio-economic policy discussed on the global and European forum, e.g. discussed by International Labour Organization (2017; Tosun, Shore, 2017). The situation of young people in individual EU countries is extensively diversified. The differences refer to the activities of young people in particular age groups and the characteristics of individual labour markets (e.g. type of agreements, work form or mode). At the same time, there are many common problems, such as greater difficulties with professional activity among people with lower levels of education. Problem of youth activity was discussed among others by: Spatarelu (2015) giving the example of Romania, where, although no serious problem exists as far as the youth unemployment rate is concerned, the high rate of NEET - Not in Education, Employment or Training (above EU average) is a problem. Jeliazkova et al. (2018) discusses the problem in Bulgaria. Salvà-Mut, Tugores-Ques and Quintana-Murci (2017) describes NEET youths aged 25-29 years-old in the context of Spanish crises, and Quintano, Mazzocchi and Rocca (2018) discusses the problem of NEET in Italy. Moreover Novák et al. (2016) presents some research results from Czechia, and Pańków (2012) from Poland.

The purpose of the article is to classify the European labour markets in terms of the situation of young people, taking into account different age groups and levels of education. In addition, an assessment of the relationship between the employment situation of young people and the selected labour market characteristics, regarding the types of concluded employment agreements, will be carried out. The analysis should answer the following questions:

1. How do the EU countries differ in terms of situation of youth on the labour market?

2. How is the situation of young people improved depending on the level of completed education?

3. Is the situation of young people related to the type of employment (full or part-time agreements)? 


\section{The research scope and procedure}

The analysis is based on the assumption that domestic labour markets differ from each other as they offer various conditions for the employment activity of young people. The subject literature presents diverse aspects determining the position of young people on labour markets, among which there are: (1) technological change, (2) demographic transformation (in some countries potential future labour shortages are expected due to declining fertility rates and increasing life expectancy - these can only be partly compensated by the immigration trends, so it should, in theory, be easier for young people to find work), (3) processes of globalization (which allow companies to relocate more easily and to reap the benefits of low-cost production regions; e.g. firms can relocate to destinations in Central and Eastern Europe and thereby create employment for young people (O'Reilly et al., 2019)), as well as (4) education and systems of vocational training in the country (Gangl, Müller, Raffe, 2003).

The conducted research does not always allow for clear indication of which factors actually determine the situation of young people on domestic labour markets. For example, the expected improvement in the situation of young people in the countries attracting corporate investments, as the manifestation of globalization, has not always been observed. In the opinion of O'Reilly et al. (2019: 3):

[...] although many jobs have been moved to Central and Eastern Europe [...]. Nevertheless, unemployment continues to be high in these countries, and it is unclear to what extent offshoring and globalization affect the overall volume of youth labour in Europe.

The article presents an attempt to identify groups of countries characterised by a similar situation of young people on the labour market, taking into account the structure of employment by age and education level. What distinguishes this analysis is the classification of countries according to the situation of young people on the domestic labour markets, taking into account the diversity of situations in particular age groups. At the basis of the analysis is the assumption - emphasised in various studies - that the situation of young people differs depending on the age group they belong to, with particularly significant differences in the younger groups. Defining the groups of countries will facilitate both the understanding of differences in young people's situations on the domestic labour markets (by age) and their connection to selected factors such as education level and types of work agreements. The purpose of the analysis is not to explain the conditions in force on a given labour market, including the legal ones, but to present the differences in domestic labour markets as a starting point for further discussion.

The analysis was conducted for 28 (or 26 in the case of part-time model estimation) EU Member States in 2017. The study was performed in four stages which cov- 
ered: (1) defining statistical indicators and collecting data, (2) preliminary data analysis, (3) hierarchical cluster analysis using Ward's minimum variance method (based on the Euclidean squared distance), (4) econometric analysis (OLS models) of the relation between the employment rates of youth and the institutional flexibility of labour market. The Eurostat database (https://ec.europa.eu/eurostat) was the source of data for all the variables in 2017. The indicators are based on the EU Labour Force Survey.

As a starting point the data showing the employment activity level of young people, according to three age groups, were collected: ER1519 - employment rate, people aged 15-19 (\%); ER2024 - employment rate, people aged 20-24 (\%); ER2529 - employment rate, people aged 25-29 (\%).

In addition, the analysis covers data reflecting the scale of the phenomenon regarding employment inactivity of young people, presented as NEET18 - young people (aged 18-24) not in employment, education or training (NEET_rates) (\%).

The situation of young people on the labour market is considered from the point of view of two factors: education level and part-time agreements popularity. For the purpose of characterizing labour markets in terms of the situation of young people, according to the level of education, the analysis included employment rates among young people aged 18-34, who were neither in education nor improving their qualifications. Three groups were created based on the level of educational attainment: 1) EMO2 - less than primary, primary and lower secondary (levels 0-2) (\%),

2) EM34 - upper secondary and post-secondary non-tertiary (levels 3-4) (\%),

3) EM58 - tertiary education (levels 5-8) (\%).

It was adopted that the employment activity of young people depends on one of the institutional labour market flexibility issue - part-time agreements ${ }^{1}$. The part-time agreements provide particular encouragement for young people who start their professional careers, especially when for some reason they are unable to take up full-time employment. It was assumed that in countries with a developed system of part-time arrangements, the tendency to take up professional activity increases, regardless of other factors. It should be noted that this tendency may be aggravated by economic conditions (e.g. high GDP linked to high wages), government policy (e.g. expenditure on social policy, benefits for young parents).

The variables characterizing part-time employment were defined as rates representing persons employed on a part-time agreements as a percentage of the same age population, in particular:

1) PT1519 - share of employed, aged 15-19, working part-time (\%),

2) $P T$ - share of employed, aged 15 and older, working part-time (\%).

Due to Eurostat methodology the distinction between full-time and part-time work was based on a spontaneous response by the respondents. The main excep-

1 This factor is connected only with one aspect of the demand side of labour market flexibility. Other factors affecting labour market flexibility are: trade unions, minimum wages, job-related information, flexi work, ability to hire and fire, barriers to entry and exit, skills etc. 
tions are the Netherlands, where a 35-hour threshold is applied and Sweden where a threshold is applied to the self-employed.

The groups of countries presenting a similar structure of young people's professional activity by age and level of education, were identified using cluster analysis methods - Ward's method. This method represents one of the agglomeration grouping methods and consists in determining the distance between all objects, followed by constructing a dendrogram illustrating the connection between each of the objects or the created groups with the objects or their most similar groups. The Euclidean squared distance was used while constructing the distance matrix.

An important step in the classification process is to determine the number of groups. It was adopted in the a priori analysis that the number of groups should not be too large and should not exceed 7 for 28 objects (countries). In order to clarify the number of groups two stopping rules were provided, the Duda, Hart, and Stork index (Je(2)/Je(1)) with associated pseudo-T-squared (Duda, Hart, Stork, 2001) and the Caliński and Harabasz pseudo-F index (Caliński, Harabasz, 1974). The first one is based on the sum of squared errors allowing to determine whether the cluster division is justified. The Duda-Hart index is local because the only information used comes from the groups being split. The information in the rest of the groups does not enter the computation (StataCorp., 2009). Having assumed the two-class division, the test authors described it as follows:

$$
\frac{\mathrm{Je}(2)}{\mathrm{Je}(1)}=\frac{\sum_{i=1}^{2} \sum_{x \in D_{i}} \mathrm{x}-m_{i}{ }^{2}}{\sum_{x \in D} \mathrm{X}-m^{2}},
$$

where: $J e(1)$ is the sum of squared errors within the group that is to be divided. $J e(2)$ is the sum of squared errors in the two resulting subgroups.

Caliński and Harabasz (1974) test for a given number of groups $(k)$ and objects $(n)$ is based on the between-cluster sum of squares and cross-products matrix $\left(B_{k}\right)$ and the within-cluster sum of squares and cross-products matrix $\left(W_{k}\right)$ :

$$
C H(k)=\frac{\operatorname{tr}\left(\mathbf{B}_{k}\right) /(k-1)}{\operatorname{tr}\left(\mathbf{W}_{k}\right) /(n-k)}
$$

The Caliński-Harabasz rule is global because the information from each group is used in the computation (StataCorp., 2009). For both stopping rules, larger values indicate more distinct clustering.

Econometric models presenting correlations between the popularity of part-time employment agreements and the employment rates of young people were developed. The analysed relation presented the following form: 


$$
E R=a_{0}+a_{1} P T+\xi
$$

where: $E R$ and $P T$ stand for, respectively, employment rates and the share of employed working part-time in the group aged $15-19$ or in the total population aged 15 or older.

One of the difficulties in interpreting the conducted econometric analysis results is establishing the direction of the correlation between variables. In the analysed case, the question is whether the flexible working time/part time agreement results in positive trends in terms of employment rates? Does the specificity of employment activity presented by young people cause that there are relatively many part-time agreements on the market? To confirm the correlation between selected characteristics of the labour market institutional flexibility and the situation of young people, the employment rate was correlated with both the share of part-time employees representing a given age group and the total value. The occurrence of a positive correlation between both variables will confirm a positive impact of the existing labour market system (approximated by the share of part-time work agreements) on the employment activity of young people.

The evaluating test based on the coefficient of determination $\left(R^{2}\right)$ values and the test of statistical significance based on Student's t-distribution were used to verify the discussed model. To assess homoscedasticity of residuals distribution, the White test for constant variance was used, which assumes fail to reject the null hypothesis (for the correct model). The test is based on the Lagrange Multiplier (LM) statistic defined as the product of the $R^{2}$ value and sample size.

\section{Econometric analyses results}

The situation of young people on domestic labour markets is strongly diversified in younger age groups. In 15-19 age group the coefficient of variation exceeds $90 \%$, whereas in 20-24 age group it drops to $23 \%$, however, in the subsequent age groups and for the entire economy it does not exceed $10 \%$. The value of employment rates in this group ranged from $2.6 \%$ in Greece to $54.5 \%$ in the Netherlands. In 2017, the average level of employment rate in $28 \mathrm{EU}$ countries in 15-19 age group reached $14.4 \%$, with the median presenting the level of $8.1 \%$. Such a large difference between the median and the mean value results from the distribution skewness. The mean value is inflated by several countries characterised by high professional activity of young people (Figure 1). These countries include Netherlands and Denmark.

Employment activity of people aged 20-24 presented a much higher level, with the mean value amounting to $51.6 \%$ and the median to $50.3 \%$ in $28 \mathrm{EU}$ countries. In individual countries it ranged from $26.1 \%$ in Greece up to $69.9 \%$ in the Netherlands. The most favourable and equalized situation was in the age group of 25-29. 
The average value of employment rate was $75.6 \%$ (median $77.8 \%$ ) and the individual countries ranged from $54.2 \%$ in Italy up to $87.5 \%$ in Malta.

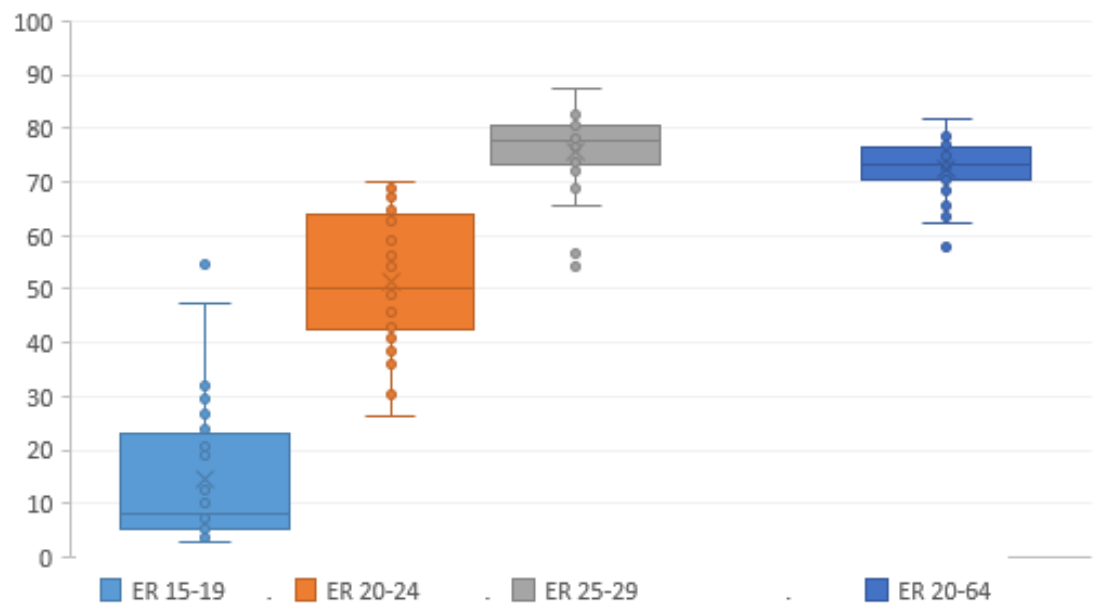

Figure 1. Diversification of employment rates in $28 \mathrm{EU}$ countries by age groups in 2017

\section{Source: author's work}

The most difficult group, in terms of professional activation and status on the labour market, includes young people not in employment, education or training (NEET). In 2017, in the group of young people aged 18-24 this indicator was approx. 13\% in the $28 \mathrm{EU}$ countries. Also in this case the differences between countries are visible. NEET18 values ranged from 5.3\% in the Netherlands to approx. $26 \%$ in Italy (Table 1).

Table 1. NEETs in 28 EU countries in 2017

\begin{tabular}{|c|c|c|c|c|c|}
\hline Indicator & Mean value & Median value & $\begin{array}{c}\text { Coefficient } \\
\text { of variation } \\
\mathbf{( \% )}\end{array}$ & $\begin{array}{c}\text { Minimum } \\
\text { value }\end{array}$ & $\begin{array}{c}\text { Maximum } \\
\text { value }\end{array}$ \\
\hline NEET $(15-24)$ & 10.4 & 9.5 & 37.2 & 4.0 & 20.1 \\
\hline NEET $(18-24)$ & 13.5 & 13.0 & 37.6 & 5.3 & 25.7 \\
\hline
\end{tabular}

Source: author's work

The cluster analyses using Ward's method allowed for defining of groups of countries featuring a similar situation of young people on the labour market. Initially, a set of three variables characterizing employment rates in individual age groups was used for the classification purposes (ER1519, ER2024 and ER2529). The obtained results were additionally compared with the fourth variable - NEET18. Adding a new variable to the classification did not affect the results. Ultimately, the results of the classification carried out for the total of 4 variables (including NEET18) were used for further analysis. 
The statistics on the classification quality - the Duda-Hart index and the Caliński-Harabasz rule - have correspondingly demonstrated the merits of grouping into 5 groups. The classification results are presented in Figure 2 and Table 2.

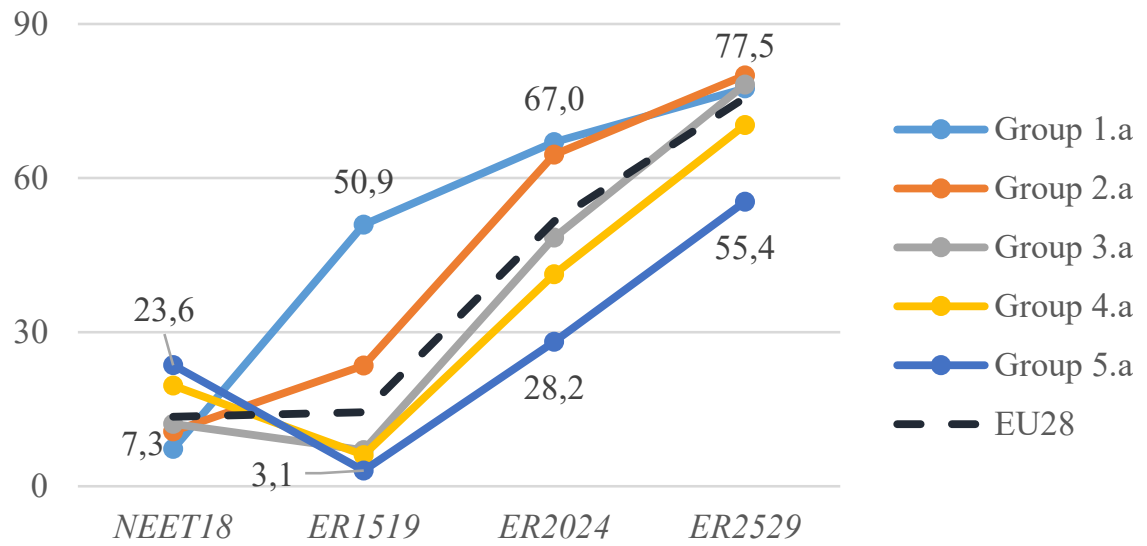

Figure 2. Cluster analysis results for $28 \mathrm{EU}$ countries, for the situation of youth on the labour market in 2017

Source: author's work

The obtained groups can be ordered from 1.a to 5.a by the level of employment activity characteristics for young people. Group 1.a covers two countries with a very good situation of young people on domestic labour markets (Denmark and Netherland). The groups featuring extremely good and bad situations can be considered relatively rare cases.

The countries from the second group (2.a) should also be included among the ones with a favourable situation of young people. What differs this group of countries from group 1.a are clearly lower values of employment rates for people aged 15-19. At the same time, the NEET phenomenon recorded in these countries is not particularly large. This may be related to the education process in which this group of participants is still involved, thus such persons are neither affecting the employment rate nor NEET and, as a result, both of these indicators have low values. Group 2.a is relatively large. It is made up of 8 out of the 28 analysed countries. Summarizing, this class can be defined as countries characterised by a high level of employment activity in the groups aged 20-24 and 25-29, an average level in the group aged 15-19 and an average NEET level.

Group 3.a (and the subsequent groups) is characterised by a much lower level of employment activity of the youngest market participants, moreover, a relatively low activity is presented by people in the group aged 20-24. In turn, in the group aged 25-29 employment rate only slightly differs from the level of groups featuring the most favourable situation (group 1.a and 2.a). It is the most numer- 
ous class, formed by 11 countries. It can, therefore, be assumed that its values represent the most popular model of employment activity, typical for young people in the EU countries.

Table 2. Cluster analysis results of $28 \mathrm{EU}$ countries for the employment activity of youth on the labour market in 2017

\begin{tabular}{|c|c|c|c|c|c|c|}
\hline Group description & $\begin{array}{c}\text { Number } \\
\text { of countries }\end{array}$ & $\begin{array}{c}\text { Country } \\
\text { name }\end{array}$ & NEET18 & ER1519 & ER2024 & ER2529 \\
\hline \multirow{2}{*}{$\begin{array}{l}\text { Group 1.a (very good) } \\
\text { the highest level } \\
\text { of employment activity } \\
\text { and low NEET level }\end{array}$} & \multirow[t]{2}{*}{2} & Denmark & 9.2 & 47.3 & 64.1 & 72.1 \\
\hline & & Netherlands & 5.3 & 54.5 & 69.9 & 82.8 \\
\hline \multirow{8}{*}{$\begin{array}{l}\text { Group 2.a (good) high } \\
\text { level of employment } \\
\text { activity in } 20-24 \text { and } \\
25-29 \text { age groups, } \\
\text { average in } 15-19 \text { age } \\
\text { group and average NEET } \\
\text { level }\end{array}$} & \multirow[t]{8}{*}{8} & Austria & 8.1 & 31.8 & 66.0 & 80.4 \\
\hline & & \begin{tabular}{|l|} 
Estonia \\
\end{tabular} & 12.3 & 12.6 & 64.3 & 80.9 \\
\hline & & Finland & 12.9 & 23.7 & 59.3 & 73.6 \\
\hline & & Germany & 8.6 & 26.9 & 64.6 & 78.3 \\
\hline & & Ireland & 13.2 & 18.9 & 63.4 & 76.6 \\
\hline & & Malta & 9.2 & 20.7 & 67.1 & 87.5 \\
\hline & & Sweden & 8.2 & 24.0 & 62.9 & 79.4 \\
\hline & & $\begin{array}{l}\text { United } \\
\text { Kingdom }\end{array}$ & 13.2 & 29.4 & 68.8 & 83.3 \\
\hline \multirow{11}{*}{$\begin{array}{l}\text { Group 3.a (average) high } \\
\text { level of employment } \\
\text { activity in the oldest age } \\
\text { group, average in } 20-24 \\
\text { age group and very low } \\
\text { employment activity } \\
\text { in } 15-19 \text { age group and } \\
\text { average NEET level }\end{array}$} & \multirow[t]{11}{*}{11} & Belgium & 12.1 & 6.0 & 38.3 & 75.1 \\
\hline & & Czechia & 8.3 & 5.0 & 49.8 & 78.3 \\
\hline & & France & 15.6 & 10.2 & 49.1 & 74.4 \\
\hline & & Hungary & 14.1 & 5.4 & 49.1 & 77.5 \\
\hline & & Latvia & 14.2 & 7.2 & 56.2 & 81.3 \\
\hline & & Lithuania & 12.1 & 6.6 & 50.7 & 84.3 \\
\hline & & Luxembourg & 8.2 & 8.4 & 42.1 & 81.4 \\
\hline & & Poland & 12.8 & 4.8 & 50.7 & 78.5 \\
\hline & & Portugal & 13.0 & 6.6 & 45.8 & 78.2 \\
\hline & & Slovakia & 15.3 & 4.1 & 46.0 & 73.1 \\
\hline & & \begin{tabular}{|l|} 
Slovenia \\
\end{tabular} & 8.0 & 12.9 & 54.3 & 78.1 \\
\hline \multirow{5}{*}{$\begin{array}{l}\text { Group 4.a (average-low) } \\
\text { average level of employ- } \\
\text { ment activity in older } \\
\text { age groups, with very } \\
\text { low employment activity } \\
\text { in } 15-19 \text { age group and } \\
\text { high NEET level }\end{array}$} & \multirow[t]{5}{*}{5} & Bulgaria & 18.6 & 4.9 & 39.2 & 69.0 \\
\hline & & Croatia & 20.2 & 7.8 & 43.1 & 68.7 \\
\hline & & Cyprus & 22.7 & 4.2 & 47.3 & 73.8 \\
\hline & & Romania & 19.3 & 8.3 & 40.8 & 74.8 \\
\hline & & \begin{tabular}{|l|} 
Spain \\
\end{tabular} & 17.1 & 5.2 & 35.9 & 65.4 \\
\hline \multirow{2}{*}{$\begin{array}{l}\text { Group 5.a low level } \\
\text { of employment activity } \\
\text { and high NEET }\end{array}$} & \multirow[t]{2}{*}{2} & Greece & 21.4 & 2.6 & 26.1 & 56.6 \\
\hline & & Italy & 25.7 & 3.5 & 30.2 & 54.2 \\
\hline
\end{tabular}


The next classes group countries presenting a relatively worst situation of young people on the labour market. Group 5.a includes Greece and Italy, i.e. the countries featuring the worst situation of young people.

Apart from the differences between groups, there are also internal differences. The situations of countries in particular groups are most diverse in terms of the indicators in younger age groups (NEET and ER1519). It is primarily evident in group 2.a with a high level of employment activity of young people and group 3.a with an average level.

The EU countries were also classified regarding the level of economic activity of young people aged 18-34, depending on their education level. The classification quality indicators, also in this case, indicated 5 groups as the optimal division. The cluster analyses results for the level of education of young people are presented in Figure 3 and Table 3.

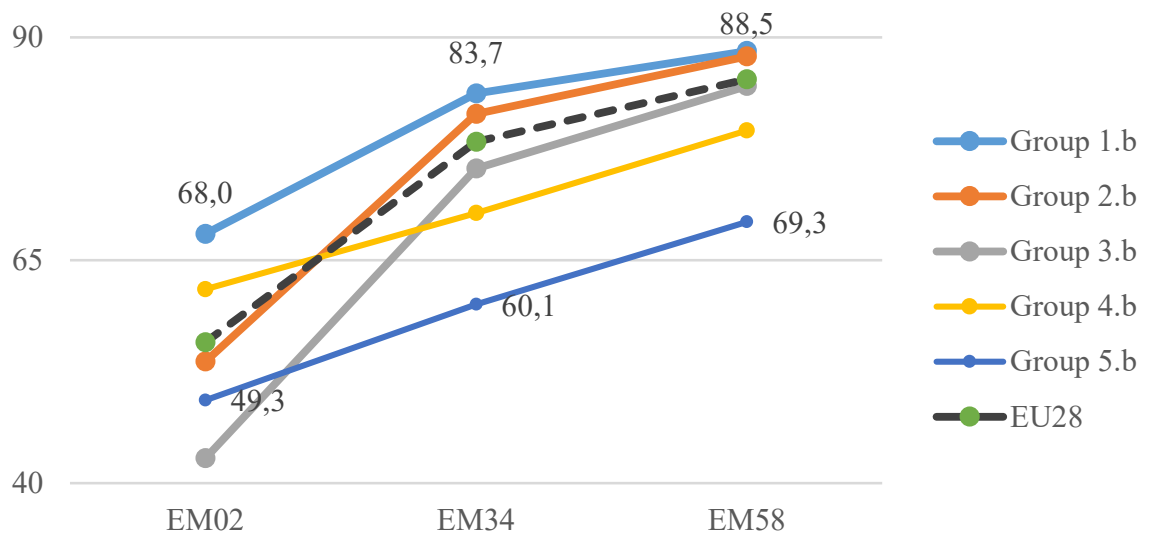

Figure 3. Average values for the classes of the EU countries, for the level of employment and education in 2017

Source: authors' work in STATA program

In all groups, the highest employment rates were obtained by the tertiary education graduates (EM58), followed by the secondary education ones (EM34), and the lowest were recorded by young people with less than primary, primary and lower secondary education (levels $0-2$ ). In the first three groups, characterised by the highest employment rates among young people, there are clear differences between the situation of at least secondary education graduates (levels 3-8) and the ones with the lowest level of education (levels $0-2$ ). In these groups, the situation of people presenting the lowest level of education shows a discrete worsening tendency against other groups of people (EM34 and EM58). This situation is characteristic for 24 out of $28 \mathrm{EU}$ countries. Only two groups (group 4.b and 5.b), covering 4 countries, follow a slightly different pattern, in which, as a rule, along with the drop in the level of education, the employment rates are lower, but 
the differences are smaller. In the case of group 4.b countries - including Cyprus, Spain - the employment rates of the least educated persons are among the higher ones, reaching the level closest to that of 9 countries in group 1.b featuring the most favourable situation in all education groups.

Table 3. Cluster analyses results for $28 \mathrm{EU}$ countries, for the employment rates and education level of youth in 2017 (based on the cluster analysis)

\begin{tabular}{|c|l|c|c|c|c|}
\hline $\begin{array}{c}\text { Group } \\
\text { number }\end{array}$ & \multicolumn{1}{|c|}{ Countries } & $\begin{array}{c}\text { Number } \\
\text { of countries }\end{array}$ & EM02 & EM34 & EM58 \\
\hline Group 1.b & $\begin{array}{l}\text { Estonia, Latvia, Luxembourg, Malta, } \\
\text { Netherlands, Portugal, Slovenia, Sweden, } \\
\text { United Kingdom }\end{array}$ & 9 & 68.0 & 83.7 & 88.5 \\
\hline Group 2.b & $\begin{array}{l}\text { Austria, Belgium, Czechia, Denmark, } \\
\text { Germany, Hungary, Poland, Romania }\end{array}$ & 8 & 53.6 & 81.4 & 87.9 \\
\hline Group 3.b & $\begin{array}{l}\text { Bulgaria, Croatia, Finland, France, Ireland, } \\
\text { Lithuania, Slovakia }\end{array}$ & 7 & 42.8 & 75.3 & 84.5 \\
\hline Group 4.b & Cyprus, Spain & 2 & 61.8 & 70.3 & 79.6 \\
\hline Group 5.b & Greece, Italy & 2 & 49.3 & 60.1 & 69.3 \\
\hline
\end{tabular}

Source: author's work in STATA program

The final element of the analysis was the identification of links between the activity of young people and the institutional flexibility of the labour market characterized by the share of people working part-time in total employment. Two indicators characterizing the share of this type of agreement in all agreements in force on the market $(P T)$ and the percentage of these agreements among young people aged 15-19 (PT1519) were used for the assessment. Due to data gaps from the classification, two countries were excluded: Bulgaria and Lithuania.

The situation on the European labour markets is highly diversified in terms of the importance of part-time agreements. This situation makes it difficult to find a method allowing to classify countries. The classification quality statistics did not allow for the determination of the number of groups unambiguously. Therefore the attempt to classify countries was abandoned. The answers to the questions asked were sought using econometric models. Initially, two analytical forms were considered, a linear and an exponential one. After the preliminary verification of the results, the linear form was indicated as best reflecting the described relation. The estimation results are presented in Table 4 and Figure 4.

The estimated parameters allow for the indication of the statistically significant relation between the employment rate of the youngest group aged 15-19 and the popularity of part-time agreements (at the level of 0.001). Regarding the situation of people aged 15-19, the popularity of part-time agreements at more than $32 \%\left(R^{2}\right)$ explained their higher level of employment activity (Figure 4). In case of selected countries, there is a clear shift away from the regression line, this ap- 
plies to Austria and Germany, which have obtained high employment rates with a relatively low share of part-time agreements, or the Netherlands and Denmark, which clearly lead to both employment rate and part-time agreements. At the same time for countries such as Poland, Belgium, Spain and Slovenia, the relatively medium-high share of part-time agreements did not translate into the corresponding level of employment among youth (values clearly below the regression line). The explanation may be related to other factors such as economic development, wage levels, social behaviour patterns, social expenditure or government policy.

Table 4. The parameters of part-time model (3) estimation of 26 EU countries in 2017

\begin{tabular}{|l|c|c|c|}
\hline $\begin{array}{c}\text { Explanatory } \\
\text { variables }\end{array}$ & Parameter (standard errors/p-value) & $\boldsymbol{R}^{\mathbf{2}}$ & $\begin{array}{c}\text { White test } \\
\boldsymbol{L M}(\boldsymbol{p} \text {-value) }\end{array}$ \\
\hline \multicolumn{5}{|c|}{ Dependent variable: $E R 1519$} \\
\hline$P T 1519$ & $0.373(0.132 / 0.0095)$ & 0.372 & $5.02(0.081)$ \\
\hline$P T$ & $1.071(0.115 / 0.000)$ & 0.681 & $5.24(0.072)$ \\
\hline \multicolumn{5}{|c|}{ Dependent variable: $E R 2024$} \\
\hline$P T$ & $0.6065(0.123 / 0.000)$ & 0.269 & $2.79(0.248)$ \\
\hline \multicolumn{5}{|c|}{ Dependent variable: ER2529 } \\
\hline$P T$ & $0.159(0.79 / 0.056)$ & 0.048 & $0.758(0.684)$ \\
\hline \multicolumn{5}{|c|}{ Dependent variable: $E R 2064$} \\
\hline$P T$ & $0.019(0.068 / 0.01)$ & 0.13 & $0.643(0.725)$ \\
\hline
\end{tabular}

Source: authors' estimations in GRETL program

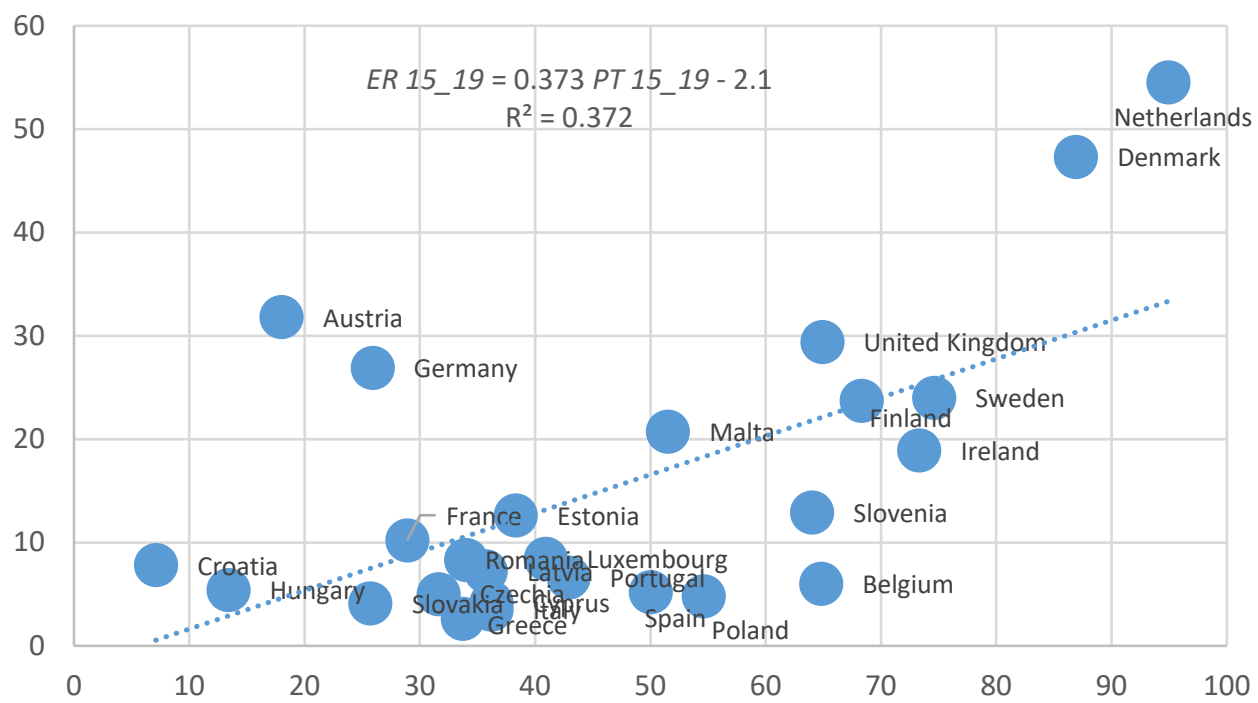

Figure 4. Employment rate vs. part-time agreements share - relation (3) estimation (age group: 15-19) for 26 EU countries in 2017

Source: authors' estimations in Excel program 
If the level of employment activity among young people up to the age of 19 is combined with the total popularity of part-time agreements on domestic labour markets, it turns out that the explanation level increases $\left(R^{2}\right.$ was over $\left.68 \%\right)$, which can be interpreted as a confirmation of the general market trend change towards part-time employment and its availability, which affects the situation of people starting their professional careers. In older age groups this correlation is identifiable to a lesser extent, which can be related to lower interest in this form of employment.

\section{Conclusions}

The article attempts to classify the European labour markets in terms of the situation of young people. Employment activity of young people presented by employment rates $(E R)$ and NEET level, as well as employment indicators taking into account the level of education and the labour market flexibility expressed in the popularity of part-time agreements, were taken into account. The most important conclusions are:

1) EU countries can be combined into groups with a similar situation of young people in particular age groups in the labour market, in such a way that a better state is linked to higher employment rates among all age groups;

2) the European labour markets are most diversified regarding the situation of people in the youngest age groups and those with the lowest level of education;

3) together with the increase in education level the employment rates of young people are improving;

4) the popularity of part-time employment significantly improves the situation of young people in the labour market. Germany and Austria stand out from other countries due to relatively low part-time employment among young people aged 15-19 (26\% Germany and 18\% Austria with the EU average at the level of 44\%) and at the same time high employment rates - over $27 \%$ (above the average in the group $-23.5 \%$, and above the EU average $-14.4 \%$ );

5) the following countries were characterised by the most favourable situation of young people: the Netherlands, Denmark, Sweden, United Kingdom, Malta, Estonia, Austria, Germany, Finland and Ireland; in turn, the most difficult situation was recorded in: Romania, Croatia, Bulgaria, Spain, Cyprus, Greece and Italy.

The analysis carried out suggests that the factors influencing the differences in the situation of young people on the domestic labour markets (in 2017) include both the level of education and the popularity of flexible forms of agreements. While changes towards the increase of youth education level require changes 
in long-term policy (including changes in the structure of the national economy and enterprises), the popularization of the part-time agreements supported by the government policy seems to be a good recommendation for an employment policy (in particular in the period of rising unemployment).

\section{References}

Caliński T., Harabasz J. (1974), A dendrite method for cluster analysis, "Communications in Statistics", no. 3, pp. 1-27.

Cazes S., Verick S. (eds.) (2013), Perspectives on labour economics for development, International Labour Office, Geneva.

Duda R.O., Hart P.E., Stork D.G. (2001), Pattern Classification and Scene Analysis, $2^{\text {nd }}$ ed., Wiley New York.

Dylkiewicz B. R. (2013), Theoretical and Empirical Implications of the Labor Market, "Studia Ekonomiczne”, no. 161, "Społeczno-Ekonomiczne Problemy Rynku Pracy”, pp. 36-43.

Gangl M., Müller W., Raffe D. (2003), Conclusions: Explaining Cross-National Differences in School-to-Work Transitions, [in:] M. Gangl, W. Müller (eds.), Transitions from Education to Work in Europe: The Integration of Youth into EU Labour Markets, Oxford University Press, Oxford, pp. 277-305.

International Labour Organization (ILO) (2017), Global Employment Trends for Youth 2017 - Paths to a better working future, Geneva.

Jeliazkova M., Minev D., Draganov D., Krasteva V., Stoilov A. (2018), Youth employment policies in Bulgaria, EXCEPT Working Papers, No. 27, Tallinn University, Tallinn, http://www.except-project.eu/working-papers/ [access: 15.11.2018].

Novák V., Vokoun M., Stellner F., Vochozka M. (2016), Institutional analysis of the contemporary regional labour market in the Czech Republic, "E+M Ekonomie a Management", vol. XIX, no. 3, pp. 4-19, http://dx.doi.org/10.15240/tul/001/2016-3-001

O’Reilly J., Leschke J., Ortlieb R., Seeleib-Kaiser M., Villa P. (2019), Youth labour in transition, Inequalities, Mobility, and Policies in Europe, Oxford University Press, Oxford.

Pańków M. (2012), Młodzi na rynku pracy raport z badania, Instytut Spraw Publicznych, Fundacja PZU, Warszawa.

Quintano C., Mazzocchi P., Rocca A. (2018), The determinants of Italian NEETs and the effects of the economic crisis, "Genus", vol. 74, no. 5, https://doi.org/10.1186/s41118-018-0031-0

Salvà-Mut F., Tugores-Ques M., Quintana-Murci E. (2017), NEETs in Spain: an analysis in a context of economic crisis, "International Journal of Lifelong Education”, vol. 37, issue 2, pp. 168-183, http://doi.org/10.1080/02601370.2017.1382016

Spatarelu E.M. (2015), Youth Insertion on Labor Market, "Procedia Economics and Finance", no. 32, pp. 1020-1026.

StataCorp. (2009), Stata: Release 11. Statistical Software, College Station, TX: StataCorp LP.

Tosun J., Shore J. (2017), The scope of European NEET outreach measures, Policy Brief V of the CUPESSE Project. 


\section{Sytuacja osób młodych na europejskich rynkach pracy - analiza ekonometryczna}

Streszczenie: Zjawisko niskiej aktywności zawodowej osób młodych, szczególnie niepracujących i niekontynuujących nauki, jest ważnym elementem polityki społeczno-gospodarczej rozważanym na forum globalnym. Raporty dotyczące problematyki aktywności zawodowej osób młodych wciąż donoszą o trudnej sytuacji w tym obszarze w wielu regionach świata, w tym w Polsce. Sytuacja osób młodych na rynkach pracy w poszczególnych państwach Unii Europejskiej jest silnie zróżnicowana, np. pod względem czasu rozpoczynania aktywności zawodowej. Celem artykuł jest pogrupowanie europejskich rynków pracy z uwagi na charakterystykę sytuacji osób młodych. Do analizy wykorzystano metody klasyfikacji, a do oceny zależności między wskaźnikiem zatrudnienia osób młodych a popularnością umów w niepełnym wymiarze czasu pracy - modele ekonometryczne.

Słowa kluczowe: analiza skupień, modele ekonometryczne, osoby młode, rynek pracy, państwa Unii Europejskiej

JEL: C38, J21

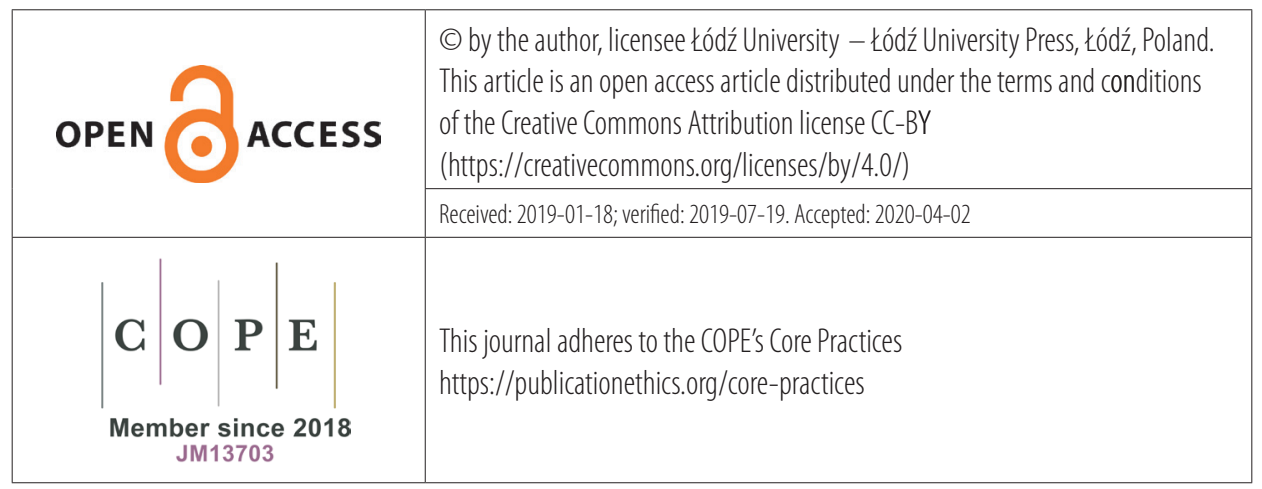

